\title{
Impact of Cooperative Milk Collection Camp on Socio- economic Conditions of Dairy Farmers in Hooghly District of West Bengal
}

\author{
Santanu Sana* and Deep Narayan Mukherjee
}

Faculty Centre for ARTD, Ramakrishna Mission Vivekananda Educational and Research Institute, Morabadi, Ranchi 834 008, India

*Corresponding author: asksantanusana@gmail.com (ORCID ID: 0000-0002-5040-8763)

Received: 03-01-2020

Revised: $10-04-2020$

Accepted: $26-05-2020$

\begin{abstract}
The study examined the impact of cooperative milk collection camp on socio-economic conditions of farmers in Hooghly district of West Bengal. The farmers cooperatively collect milk in the collection camp namely Bholanath Dairy and milk was sent to Arambagh chilling plant. The primary data were collected from 60 cooperative farmers and 10 agricultural farmers through purposive random sampling method. The present collection camp covers 7 villages with 402 milk farmers and total milk collected in last 6 months was 216000 litres. The average herd size per family was 1.28 for local cow and 0.92 for crossbreed cow. The major component of variable costs incurred were feed which includes green fodder, dry fodder concentrates and grains. The total variable cost incurred by dairy farmer per animal per year was ₹ 26552.44. The total cost of producing milk per animal per year was ₹ 30149.99. The gross return obtained per animal per year was ₹ 51450.00. Lack of technical facility, high cost of cattle feed, improper grading; measurement \& timings of milk collection in the camp were the major problems of the dairy farmers. The study farther showed that the families which were attached with dairy activities side by side of agriculture generated more income than solo agricultural families. It also found that the number of dairy farmers decreased in the cooperative milk collection camp with the increase of distance. So, this model might be replicated in every villages. There was also a scope for reduction in cost of milk production by using modern methods and technologies of dairy farming that was completely absent in the study area.

\section{Highlights}

(0) The main problems faced by the dairy farmers is the lack of revenue due to unorganised supply chain management in many parts of rural West Bengal. The present study focuses to find out the impact of cooperative dairy farming on the income of dairy farmers.
\end{abstract}

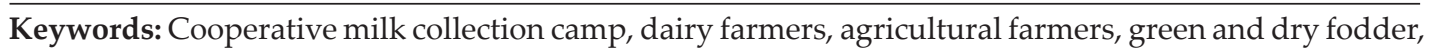
concentrate

Agriculture is the single most activity, which is not only the reliable source of food throughout the world (Mukherjee and Vasudev, 2014) but also provides largest employment in many third world countries (Shuya and Sharma, 2014; Gadad, 2015). About $61.5 \%$ of the 1300 million Indian population is rural and dependent on agriculture (Agricultural Cencus, 2011). The continuous and intensive agriculture practices for meeting the objective of food security, leads to over exploitation of the natural resources. In this situation the dairy as allied sector of agriculture plays a very important productive role in Indian economy because the contribution of milk is huge in GNP as a second largest agricultural product, only after rice. Besides, crop husbandry practices that completely based on land can only provide seasonal

How to cite this article: Sana, S. and Mukherjee, D.N. (2020). Impact of cooperative milk collection camp on socio-economic conditions of dairy farmers in Hooghly district of West Bengal. Economic Affairs, 65(2): 295-300.

Source of Support: None; Conflict of Interest: None 
income to the farmers whereas dairy provides not only off seasonal employment but also generate regular flow of income throughout the year to the farmer (Sarker and Ghosh, 2008).

In recent period, per capita consumption of food grain has become stagnant or on decline, but in the cases of livestock product it has significantly increased (Kumar et al. 2011). In the early stages of economic development, agro-based industries occupied a prominent position in the industrial sector (Yasmeen et al. 2016). Dairy farming in India has grown hugely from being a traditional family run occupation to an organized industry with technological specializations (Simranjit et al. 2017). Dairy cooperatives are the integral part of the dairy development and milk marketing in India that was started through "operation flood" in 1970 (Gadad, 2015). Milk cooperative is the key element for overall development of rural economy. Though it was started 70's era, but it was not effective throughout the country (Singh and Pundir, 2000). The rural economic situation of states like Gujarat, Tamil Nadu, Maharastra and Karnataka has developed through development of cooperative dairy (Benni, 2005). These states have taken AMUL type cooperative structure that is (i) In state level, the State Milk Marketing Federation (ii) in district level, the District Milk Producer Cooperatives Union and (iii) in Village level, Primary Milk Producer's Co-operative Society. In West Bengal, this structure was also present from 1983 through West Bengal Cooperative Milk Producers Federation Limited (WBCMPFL). But private or non-cooperative dairy is prominent in West Bengal (Sarker and Ghosh, 2008).

In this perspective, the study of a new cooperative milk collection camp that had started in a farming community in state like West Bengal is very relevant. Though the camp does not fully work as a Primary Milk Producer's Co-operative Society, it has potentiality to develop. The study would throw light on the extent of coverage under cooperative milk collection camp, the economic difference of dairy farmers and agriculture farmers, and problem associated with dairy activities that would enable the academicians and policy makers to formulate and implement appropriate policies for a balanced and integrated agricultural development.

\section{METHODOLOGY}

The study area and the cooperative milk collection camp was purposively selected as there was no milk cooperative in the region and as the cooperative had newly started. The study is predominantly based on primary data that were collected by using pretested schedule through field survey. 60 cooperative dairy farmers and 10 agricultural farmers were randomly selected for getting primary data and the secondary information were also collected from the Secretary of the Cooperative Society for the study. The collected data were coded, classified so that the findings become meaningful. Besides, tabular analysis was also done of the coded and classified data that involved the computation of means, percentages. Budgeting technique was used for working out the costs-returns of the milk production. Garrett ranking technique was also used for evaluating the problems faced by the farmers.

\section{RESULTS AND DISCUSSION}

The secondary data revealed that the milk collection cooperative namely Bholanath Dairy was started on $25^{\text {th }}$ August, 2017 at Haruah village of Pursurah Block, Hooghly. It was started with 200 farmers for saving them from the exploitation by the traditional traders and middlemen. The timings of milk collection were 7 am to 10 am and $6 \mathrm{pm}$ to $8: 30 \mathrm{pm}$. The collected milk was sent to the Arambag chilling plant and then those were sent to different processing units. In recent period the camp covers 7 villages with 402 milk farmers and total milk collected in last 6 months was 216000 litres. The distribution of milk producing farmers in different villages are presented in table 1 . It can be noticed that most of the milk producing farmers under the collection camp were from Chiladangi $(47.76 \%)$ and Haruah (23.38\%) villages and in the case of Gholdigrui (06.71), Balarampur (08.45\%), Gopimohanpur $(9.95 \%)$ the number of farmers were low, where it was very low in Hati $(1.74 \%)$ and Sundurush $(3.23 \%)$. It was mainly due to the fact that Chiladangi and Haruah are adjoining villages of the collection camp, in the case of Gholdigrui, Balarampur and Gopimohanpur, they are slightly away (about $1.5 \mathrm{~km}$ ) from the village. But Hati and Sundurush are far away (about 2.5) from the village so the numbers of milk producing farmers were very low in the camp-cooperative. 
Table 1: List of Villages and number of dairy farmers under the cooperative milk collection camp

\begin{tabular}{llll}
\hline Sl. No. & Village name & $\begin{array}{l}\text { No. of dairy } \\
\text { farmers }\end{array}$ & Percentage \\
\hline 1 & Haruah & 94 & 23.38 \\
2 & Gopimohanpur & 40 & 9.95 \\
3 & Chiladangi & 192 & 47.76 \\
4. & Gholdigrui & 27 & 06.71 \\
5 & Balarampur & 34 & 08.45 \\
6 & Hati & 7 & 01.74 \\
7 & Sundurush & 13 & 03.23 \\
\hline & Total & $\mathbf{4 0 2}$ & $\mathbf{1 0 0}$ \\
\hline
\end{tabular}

\section{Composition of the Dairy Animals of Sample Farmers}

In the study area, there were dairy animals except buffaloes. Hence, dairy farming forms a major element as an additional source of income of the study area for the farmers. The details about the Composition of dairy animals of sample farmers and their value are presented in Table 2.

Table 2: Composition of dairy animals of sample farmers

\begin{tabular}{|c|c|c|c|c|}
\hline $\begin{array}{l}\text { Sl. } \\
\text { No. }\end{array}$ & $\begin{array}{l}\text { Type of } \\
\text { animals }\end{array}$ & $\begin{array}{l}\text { Total no. of } \\
\text { animals }\end{array}$ & $\begin{array}{l}\text { Average } \\
\text { herd size } \\
\text { per sample } \\
\text { farmers }\end{array}$ & $\begin{array}{l}\text { Average value } \\
\text { of animals } \\
\text { (present market } \\
\text { value) ₹ }\end{array}$ \\
\hline 1 & Local & & & \\
\hline$\overline{(A)}$ & Bulls & 7 & 0.12 & 12000.00 \\
\hline (B) & Cows & 77 & 1.28 & 11375.00 \\
\hline 2 & Crossbr & eed & & \\
\hline (A) & Bulls & 0 & 0 & NA \\
\hline (B) & Cows & 55 & 0.92 & 25866.00 \\
\hline
\end{tabular}

Source: Primary data and author's calculation.

It is noticed from table 2 that the number of local bulls were 7 and the average value of these bulls was ₹ 12000.00 , the local cows were 77 and their average value was $₹ 11375.00$. The number of cross breed cows were 55 and their total value was ₹ 1422630 .

The number of local cows were more than crossbreed cows, it was mainly due to lack of knowledge about dairy farming of the sample farmers that they had a wrong perception about crossbreed cows that those cows feed more, easily susceptible to diseases and the milk was watery.

\section{Pattern of Milk Marketing of the Dairy Farmers}

The selling pattern of milk by the sample farmers to the collection camp were presented in the table 3 . The average quantity of milk sold differed according to the stage of lactation period. In the initial period of lactation, they sold 4.12 litres in the morning and 3.60 litres in the evening. In the middle period of lactation, they sold 3.80 litres in the morning and 2.98 litres in the evening. Whereas in the end period of lactation the quantity of milk sold decreased. They sold 2.79 litres in the morning and 1.70 litres in the evening.

Table 3: Pattern of milk marketing by the dairy farmers

\begin{tabular}{lllll}
\hline \multirow{2}{*}{$\begin{array}{l}\text { S1. } \\
\text { No. }\end{array}$} & Lactation period & \multicolumn{3}{c}{$\begin{array}{c}\text { Average quantity of milk } \\
\text { marketed (kg/day) }\end{array}$} \\
\cline { 2 - 5 } & & Morning & Evening & Total \\
\hline 1 & $\begin{array}{l}\text { Initial period (1 }{ }^{\text {st } 3} \\
\text { lactation) }\end{array}$ & 4.12 & 3.60 & 7.72 \\
2 & $\begin{array}{l}\text { Middle period (3-5 } \\
\text { lactation) }\end{array}$ & 3.80 & 2.98 & 6.78 \\
3 & $\begin{array}{l}\text { Terminal period (6 \& } \\
\text { above lactation) }\end{array}$ & 2.79 & 1.70 & 4.49 \\
\hline
\end{tabular}

Source: Primary source and author's calculation.

\section{Costs and Returns Structure in Milk Production}

The money spent for purchasing various inputs in milk production are presented in table 4 . The different inputs of dairy farming are dry fodder, green fodder, grains, concentrates, veterinary medicines and labour charges etc.

Total variable cost was per animal per year was ₹ 30894.00 in dairy farming. The major items of variable costs were grains, concentrate, green fodder and dry fodder. The cost grains contributed the maximum cost i.e. ₹ 9600.00. The concentrates also contributed huge cost that was ₹ 7800.00. It is because concentrates are responsible for high milk productivity. The cost of dry fodder and the green fodder were $₹ 2250.00$ and $₹ 3744.00$ respectively. The main objective of any type of farming is to maximize the production. In case of dairy farming, it can be achieved by feeding the dairy animal with optimum rate.

Thus, the costs for feed contributes more than half 
Table 4: Cost involved in milk production (per animal-per annum)

\begin{tabular}{|c|c|c|c|c|c|}
\hline Sl. No. & Particulars & Unit & Quantity/year & Unit cost & Cost/year In P ₹ \\
\hline$(\mathrm{A})$ & Variable cost & & & & \\
\hline 1 & Green Fodder & $\mathrm{Kg}$ & 6240 & ₹ 60/qt & 3744.00 \\
\hline 2 & Dry Fodder & $\mathrm{Kg}$ & 2250 & ₹ $100 /$ qt & 2250.00 \\
\hline 3 & Concentrates & $\mathrm{Kg}$ & 650 & $₹ 1200 / \mathrm{qt}$ & 7800.00 \\
\hline 4 & Grains & $\mathrm{Kg}$ & 1200 & $₹ 800 / q \mathrm{t}$ & 9600.00 \\
\hline 5 & Labour & Man-Days & $30 \mathrm{MDs}$ & ₹ $200 / M D$ & 6000.00 \\
\hline 6 & Veterinary \& medicine & $₹$ & & & 1000.00 \\
\hline 7 & Miscellaneous cost & $₹$ & & & 500.00 \\
\hline (A) & Total Variable cost & $₹$ & & & 30894.00 \\
\hline (B) & Fixed cost & & & & \\
\hline 1 & Depreciation on buildings & $₹$ & & & 1740.00 \\
\hline 2 & Depreciation on animals & $₹$ & & & 1530.50 \\
\hline 3 & Interest on Fixed cost $(10 \%)$ & $₹$ & & & 327.05 \\
\hline$(\mathrm{A})$ & Total Fixed cost & $₹$ & & & 3597.55 \\
\hline (B) & Total cost $(A+B)$ & $₹$ & & & 34491.55 \\
\hline
\end{tabular}

Source: Primary data and author's calculation.

of the costs of dairy farming. The fixed cost of dairy farm is depreciation on building and animals. The cost of depreciation on building and animals were $₹ 1740.00$ and $₹ 1530.00$, respectively. The interest on the fixed capital was ₹ 3597.55. The total fixed cost and total cost for dairy farming were ₹ 3597.55 and $₹ 34491.55$. The returns from dairy farming are come by selling of milk, dung (used as fuel and for preparing manure) and calves. The details regarding the returns from the dairy farming are presented in Table 5.

Table 5: Returns from milk production (per animalper annum)

\begin{tabular}{|c|c|c|c|c|c|}
\hline $\begin{array}{l}\text { S1. } \\
\text { No. }\end{array}$ & Particulars & Unit & $\begin{array}{l}\text { Quantity/ } \\
\text { year }\end{array}$ & $\begin{array}{l}\text { Unit } \\
\text { Costs }\end{array}$ & $\begin{array}{l}\text { Returns/ } \\
\text { year ₹ }\end{array}$ \\
\hline 1 & Sale of milk & $\mathrm{Kg}$ & 1710 & ₹ $25 / \mathrm{kg}$ & 42750.00 \\
\hline 2 & Sale of dung & Tons & 2 & ₹ 600/ton & 1200.00 \\
\hline \multirow[t]{3}{*}{3} & Sale of calves & Numbers & 1 & & 7500.00 \\
\hline & Gross returns & $₹$ & & & 51450.00 \\
\hline & Net returns & $₹$ & & & 16958.45 \\
\hline
\end{tabular}

Source: Primary data and author's calculation.

In the return section of the dairy farming, the maximum returns come from sale of milk which was ₹ 42750.00. The contribution of sale of calves and sale of manure in returns were $₹ 7500.00$ and $₹ 1200.00$ respectively. The gross return obtained from per animal per year was ₹ 51450.00. The net return was ₹ 16958.45 per animal per year. So, it could be said that from the dairy farming, the farmers can achieve a huge amount of profit side by side of agriculture that helps for improving their economic condition.

\section{Income Difference of Different Activities in The Study Area}

The income difference of different activities of the study area are presented in the table 6. Separately the income data of 10 farmers who completely depend on agriculture were collected for making comparison with other activities.

Table 6: Income difference of different activities (per annum)

\begin{tabular}{lll}
\hline S1. No. & Activities & Income $(₹) /$ annum \\
\hline 1 & Agriculture & 110000.00 \\
2 & Agriculture + dairy & 131300.01 \\
3 & Others + Dairy & 172000.00 \\
\hline
\end{tabular}

Source: Primary data and author's calculation.

Average income of the agriculture families in the study area was ₹ 110000.00 per annum where agriculture + dairy and dairy + others (shopkeeper/ business/teacher etc.) were ₹ 131300.00 and ₹ 172000.00 respectively. So, it can be said that dairy provides an additional earnings side by side their main occupation. 


\section{Problems Faced by the Farmers in Economically and Marketing of Milk}

The problems faced by the milk producing farmers were ranked by using Garett ranking method and are presented in Table 7 and 8 .

Table 7: Economic constraints faced by dairy farmers

\begin{tabular}{lllll}
\hline $\begin{array}{l}\text { S1. } \\
\text { No. }\end{array}$ & Constraints & $\begin{array}{l}\text { Garrett } \\
\text { total score }\end{array}$ & \multicolumn{2}{c}{ Garret mean } \\
\hline 1 & $\begin{array}{l}\text { Lack of technical } \\
\text { facility }\end{array}$ & 3224 & 53.73 & $2^{\text {nd }}$ \\
2. & $\begin{array}{l}\text { High cost of } \\
\text { crossbreed cow }\end{array}$ & 2507 & 41.78 & $4^{\text {th }}$ \\
3 & $\begin{array}{l}\text { High cost of cattle } \\
\text { feed }\end{array}$ & 3239 & 53.98 & $1^{\text {st }}$ \\
4 & $\begin{array}{l}\text { High cost of } \\
\text { veterinary service }\end{array}$ & 3176 & 52.93 & $3^{\text {rd }}$ \\
\hline
\end{tabular}

Source: Primary data and author's calculation.

Table 8: Marketing constraints faced by dairy farmers

\begin{tabular}{|c|c|c|c|c|}
\hline $\begin{array}{l}\text { Sl. } \\
\text { No. }\end{array}$ & Constraints & $\begin{array}{l}\text { Garrett } \\
\text { total score }\end{array}$ & $\begin{array}{l}\text { Garret } \\
\text { mean score }\end{array}$ & Rank \\
\hline 1 & Low price of milk & 3240 & 54 & $1^{\text {st }}$ \\
\hline 2 & Delay in getting price & 2719 & 45.31 & $4^{\text {th }}$ \\
\hline 3 & $\begin{array}{l}\text { Timing of milk } \\
\text { collection \& } \\
\text { measurement of milk }\end{array}$ & 2954 & 49.23 & $3^{\text {rd }}$ \\
\hline 4 & $\begin{array}{l}\text { Improper grading of } \\
\text { milk }\end{array}$ & 3087 & 51.45 & $2^{\text {nd }}$ \\
\hline
\end{tabular}

Source: Primary data and author's calculation.

In the study area the high cost of cattle feeds was the major problem which ranked I with a mean score of 53.98. Lack of technical facility was ranked II with a mean score of 53.73. High cost of veterinary service ranked III with a mean score of 52.93 and high cost of crossbreed cow was ranked IV with a mean score 41.78 . The sample farmers expressed High cost of cattle feeds as the major problem in milk production. The farmers produced compounded feeds by mixing other low quality feeds like paddy husk, paddy straw, wheat straw, wheat bran, etc. with concentrate so that the cost feed might be reduced. The modern technology of dairy farming was not applied in the area. The farmers did not use any machines like milking machine, fodder cutting machine. It was mainly due to lack of knowledge and awareness about dairy farming. Majority of the farmers (52.93 mean score) also expressed their dissatisfaction over the Non-availability of emergency veterinary services and artificial insemination facilities. This may be mainly because of limited veterinary doctors in the study area. High cost of cross-breed cattle was also one of the problem in milk production. So, the animal husbandry department need to undertake the cattle breeding work on larger scale to supply good milch breeds to the dairy farmers.

Farmers said that the price fixed for milk that cannot generate enough profit. Low price of milk was ranked I with a mean score of 54 . Farmers also expressed their dissatisfaction over the grading of milk. Improper grading was ranked II with a mean score of 51.45. Farmers experienced that there was partiality in timing of milk collection \&malpractices in measurement of milk. This problem was ranked III with a mean score of 49.23. Farmers opined the difficulty in getting the payment in time. This problem was ranked IV with a mean score of 45.31 .

Farmers opined that the price of milk cannot generate enough profit. This may be because of increasing cost of inputs required for milk production. Farmers also expressed their dissatisfaction over the grading of milk. This may be mainly because the camp did not give much importance to the grading of the commodity. Farmers opined that there was prevalence of malpractices in timing of milk collection \& measurement of milk. They said that in this cases partiality was occurred. It might be have wrong perception of people. Farmers experienced the difficulty in getting the payment for their produce in time. The amount was paid through their bank account. The delay occurred because there may be chance of bank related problem.

\section{CONCLUSION}

The findings showed that the number of dairy farmers decreases in the cooperative milk collection camp with the increase of distance from the camp. So, this model can be started in every village. The non-dairy farmers should be encouraged to start the dairy activities for increasing their income level. In this case the members of the camp may be act as a role model for motivating the non-dairy farmers. Besides following suggestions canbe taken for better performing of the camp.

1. There buffalos were not reared, farmer should be influenced to start buffalo farming 
2. There is a scope for reduction in cost of milk production by using modern methods and technologies (quality feed and different equipment) of dairy farming that is completely absent in the study area.

3. The production efficiency of dairy animals may be increased with selection of cross breed animal due to better milk production as compared to other local breeds.

4. The government should focus on increasing emergency veterinary services and artificial insemination facilities in the region.

5. Conduct of animal fairs, milking competitions for encouraging the dairy farmers that may boost the milk production. Besides it may cause a 'war' like situation among the milk producers and may encourage non-dairy farmers to involve in dairy activity.

\section{REFERENCES}

Benni, B.S. 2005. Dairy Cooperatives: Management and Practice. Rawat Publications, New Delhi.

Gadad, P.C. 2015. Milk producers co-operative societies in betterment of dairy farmers economy - an analysis. An MSc Thesis submitted to Dharwad University of Agricultural Sciences.
Kumar, P., Kumar, A., Shinoj, P. and Raju, S.S. 2011. Estimation of demand elasticity of food commodities in India. Agriculture Economics Research Review, 24 (1): 1-14.

Mukherjee, D.N. and Vasudev, N. 2014. Economic analysis of marketing performances in the Rythu bazars (direct marketing) in Hyderabad city. Economic Affairs, 59: 621627.

Sarker, D. and Ghosh, B. Kumar. 2008. Economics of milk production in West Bengal: Evidence from Cooperative and non-Cooperative farms. Journal of Economics Business, 11(1\&2): 132-152

Shuya, K. and Sharma, A. 2014. Impact and constraints faced by the borrowers of cooperative bank finance in Nagaland. Economic Affairs, 59: 561-567.

Simranjit, Sodhi, S.S., Singh, J., Kashyap, N., Kansal, S.K. and Verma, H.K. 2017. Perception of Member Dairy Farmers about Animal Health Care Services and Input Facilities Provided By Milkfed. Journal of Animal Research, 7: 957-963.

Singh, K. and Pundir R.S. 2000. Cooperative and Rural Development in India. Institute of Rural Management, Anand-388 001, India. https://www.irma.ac.in/pdf/ randp/979_76324.pdf.

Yasmeen, Patil, S.S. and Vijaykumar, N. 2016. Factors responsible for the performance of cooperative sugar factories in North-Eastern Karnataka. Economic Affairs, 61: $225-230$. 